\title{
FSHB wt Allele
}

National Cancer Institute

\section{Source}

National Cancer Institute. FSHB wt Allele. NCI Thesaurus. Code C104398.

Human FSHB wild-type allele is located in the vicinity of $11 \mathrm{p} 13$ and is approximately $4 \mathrm{~kb}$ in length. This allele, which encodes follitropin subunit beta protein, is involved in induction of sperm and egg production. Mutations in this gene are associated with folliclestimulating hormone deficiency, isolated. 